\title{
Customer Service Mechanism Analysis At Bank Bjb Branch Of Tangerang City
}

\author{
Rachmat Gustiana \\ gustianarachmat123@gmail.com \\ Mustofa \\ mustofa.website@gmail \\ Beby Pebri Nurjaman \\ bebypebrynurjaman@gmail.com \\ 1)2)3)STISIP Yuppentek Tangerang
}

\begin{abstract}
This study aims to explain the service mechanism at Bank BJB, Tangerang City Branch to its customers. The research objective was to explain the service level and customer satisfaction index value of the Bank BJB Branch of Tangerang City. The research method used is quantitative method with descriptive type. To measure the level of service used Likert scale analysis and to measure customer satisfaction used customer satisfaction index analysis.

The results showed that the research hypothesis can be accepted, with a service level of $70.52 \%$, which is above the critical value of acceptance of hi potesis by $60 \%$. The results of the customer satisfaction index analysis resulted in a value of 89.53 which was included in the service class category A class which indicated that the services provided by the Bank BJB Branch of Tangerang City were very good.
\end{abstract}

Keywords: Service1, Bank BJB 2, Customer Satisfaction Level. 


\section{PRELIMINARY}

With the development of the banking business, it is banks that are able to provide the best service that are expected to be able to win the competition with other banks. By providing the best service, the bank will have the greatest opportunity to get loyal customers.

Among the many banks in Indonesia, Bank Jabar-Banten (BJB) is one of them. BJB Bank has been operating since 1961 which is a bank owned by the West Java Provincial Government. The position of BJB Bank as a bank for regional development places BJB as a bank with a strategic position in winning some of the competition in reaching potential customers in West Java and Banten.

The strategic position of BJB Bank will certainly make it easier for BJB banks to face competition, because all regional government budgets in West Java and Banten are included in the payroll system of the State Civil Service (ASN) in these two regions. In addition, the existence of BJB Bank is one of the complementary tools for implementing regional autonomy in the banking sector.

As a complement to the implementation of regional autonomy in the banking sector, BJB Bank has:

1. Acting as a driving force and driving force for regional growth and development.

2. Acting as a regional cash holder.

3. Acting as one of the regional revenues.

4. Play a role in operationalizing its business as a commercial bank.

The three strategic roles, from number 1 to 3, make it possible for BJB Bank to attract customers apart from the State Civil Servants (ASN) as well as several companies that have contracted work with local governments. Thus, in running its business, Bank BJB has benefited greatly from its appointment as a partner for local governments in West Java and Banten.

Specifically, in Tangerang City, apart from Bank BJB Tangerang City Branch, it has three strategic roles above, in encouraging development, Bank BJB Tangerang City Branch is able to make a real contribution to Corporate Social Responsibility (CSR) funds. As a partner of the Tangerang City Government, in the last few years, Bank BJB Tangerang City Branch has assisted the Tangerang City Government in providing assistance funds for the construction of livable houses, providing assistance for people with disabilities, such as wheelchairs and hearing aids, through the distribution of CSR funds from BJB Bank Tangerang City Branch.

To develop its business, Bank BJB Tangerang City Branch is not only a partner for local governments, but also acts as a commercial bank. In running its business as a commercial bank, Bank BJB Tangerang City Branch has created innovative products for public service, including savings and mutual funds, housing loans, business loans and so on.

However, to compete as a commercial bank, the Tangerang City Branch of BJB Bank is required to optimize its services, lest the bureaucratic image of service as a government bank be attached to this bank.

Thus it can be formulated that rum $\mathrm{u}$ san problem in this research is how are level of service and level of customer satisfaction with the services provided by the Bank BJB Branch of Tangerang to its customers? While the purpose of this study was to find 
out and explain the level of service and level of customer satisfaction with the services provided by the Bank BJB Branch of Tangerang to the its customers.

\section{RESULTS AND DISCUSSION}

In this study, the samples taken were 100 customers who had at least three times made transactions or received services directly at the Bank BJB Tangerang City Branch Office in the last two months and were in the location when data collection took place. From the results of the calculation of the characteristics of respondents based on gender, it can be seen that most of the respondents who filled out the research questionnaire were dominated by men totaling 72 respondents $(72.00 \%)$ while respondents who were female were 28 respondents $(28.00 \%)$ of the total. 100 respondents.

To measure the validity level of the data from the respondents' answers, item analysis was used, namely correlating the score of each item with the total score, which is the sum of each item score with a critical value of 0.300 . The results of data validity testing can be seen in the following table.

Table 1.

Results of Data Validity Analysis

\begin{tabular}{|c|c|c|}
\hline No.Item & Correlation coefficient & Information \\
\hline 1. & 0,445 & Valid \\
2. & 0,749 & Valid \\
3. & 0,561 & Valid \\
4. & 0,451 & Valid \\
5. & 0,709 & Valid \\
6. & 0,678 & Valid \\
7. & 0,678 & Valid \\
8. & 0,615 & Valid \\
9. & 0,676 & Valid \\
10. & 0,665 & Valid \\
\hline
\end{tabular}

Source: Results of Questionnaire Quantitative Data Analysis, 2020 Research

By considering the correlation value for each item in the respondent's answer regarding the level of customer approval of the Bank BJB Tangerang City Branch, to meet the needs of its customers, the result is that all correlation values are greater than the validity critical value (0.3). Thus it can be concluded that all respondents' answers to each item in the questionnaire are declared valid, can be included in further testing. Then for measure the level of reliability of data from respondents, used analysis of Cronbach's Alpha with the critical value of 0,600 . The test results reliability of data can be seen in the following table. 
Table 2.

Results of Data Reliability Analysis

\begin{tabular}{|l|c|c|c|}
\hline Respondents' Answers & $\begin{array}{c}\text { Cronbach's } \\
\text { Alpha } \\
\text { Correlation }\end{array}$ & $\begin{array}{c}\text { Critical } \\
\text { Value }\end{array}$ & Conclusion \\
\hline $\begin{array}{l}\text { Customer approval for } \\
\text { services at BJB }\end{array}$ & 0,816 & 0,600 & Reliable Data \\
\hline
\end{tabular}

Source: Results of Questionnaire Quantitative Data Analysis, 2020 Research

From the results of the reliability analysis above, it is known that the correlation value of Cronbach's Alpha calculated by SPSS for alpha analysis is 0.816 . With the results of these calculations when compared with the critical value (0.600), the calculation results are greater, so it can be concluded that the data from the respondents' answers can be declared reliable.

To measure the normality level of the data from the respondents' answers, the results of the calculations are shown in the following table.

Table 3.

Results of Normality Testing of Research Variable Data

\begin{tabular}{|l|c|}
\hline \multicolumn{1}{|c|}{ Unit of Analysis } & Service \\
\hline N Valid & 100 \\
\hline Missing & 0 \\
\hline Skewness & 0.844 \\
\hline Std. Error of Skewness & 0.465 \\
\hline Kurtosis & 0.515 \\
\hline Std. Error of Kurtosis & 0.717 \\
\hline
\end{tabular}

Source: Results of Questionnaire Quantitative Data Analysis, 2020 Research

Based on the data in table 3, to find out whether the data from each variable spreads normally or not, a calculation is carried out by dividing the skewness value (curve slope) by the standard error and the kurtosis value (curved curve) with the standard error. If the hasl value for the value of skewness and kurtosis is in the range of -2 to +2 , then the data from the variable can be concluded as normal.

Table 4.

Results for the Value of Skewness and Kurtosis

\begin{tabular}{|c|c|c|c|}
\hline Parameter & Value & Quotient & Conclusion \\
\hline Skewness & 0.844 & \multirow{2}{*}{1.815} & \multirow{4}{*}{$\begin{array}{l}\text { Data spread normally } \\
\text { due to quotient } \\
\text { skewness and kurtosis } \\
\text { with std. the error } \\
\text { returns a value } \\
\text { between }+2 \text { to }-2\end{array}$} \\
\hline Std. Error of Skewness & 0.465 & & \\
\hline Kurtosis & 0.515 & \multirow[b]{2}{*}{1.718} & \\
\hline Std. Error of Kurtosis & 0.717 & & \\
\hline
\end{tabular}

Source: Results of Questionnaire Quantitative Data Analysis, 2020 Research 
Based on table 4.It can be concluded that for the data from the research variable, namely about the services of the Tangerang City Branch BJB Bank, it has normal data distribution, because the quotient value of skewness and kurtosis is in the range of -2 to +2 .

To carry out descriptive hypothesis testing, there are several steps that researchers need to take, including:

1. Converting the respondent's attitude, the previous calculation has been carried out by producing the conversion frequency.

2. Converting the results of the gradation of the choice of respondent's attitude according to the number of respondents (100 people) and the statement items (10 items) that were submitted.

3. Adding up all respondents' answers to all gradations of the respondent's answers.

4. Make a Likert scale based on the level of gradation.

5. Enter the total number of respondents' responses into the Likert scale.

The calculation of the descriptive hypothesis test analysis of the variable customer approval for the implementation of services provided by the Bank BJB Tangerang City Branch is as follows:

1. Converting the number of respondents with the number of items in the gradation statement of the respondent's choice of attitude:

(?) The number of respondents who answered the value $5 \times 186=930$

(-) The number of respondents who answered the value $4 \times 282=1.128$

(2) The number of respondents who answered the value of $3 \times 424=1.272$

(2) The number of respondents who answered the value of $2 \times 88=176$

(2) The number of respondents who answered the value $1 \times 20=20$

2. Determine the highest score, lowest score, and average value of the respondent's answer:

(2) The highest value is obtained if all respondents' answers are given a rating of 5 $(100 \times 10 \times 5=5,000)$.

(2) The lowest value is obtained if all respondents' answers are given an assessment of $1(100 \times 10 \times 1=4,000)$.

(2) The average value is obtained if all respondents' answers are given an assessment of 3 or by adding the highest and lowest values then dividing by 2 $(100 \times 10 \times 3=3,000)$.

3. Adding all the respondents' answers to all the respondent's answer gradations: $930+1.128+1.272+176+20=3.526$

4. Membuat skala likert berdasarkan tingkat gradasi Make a Likert scale based on the level of gradation

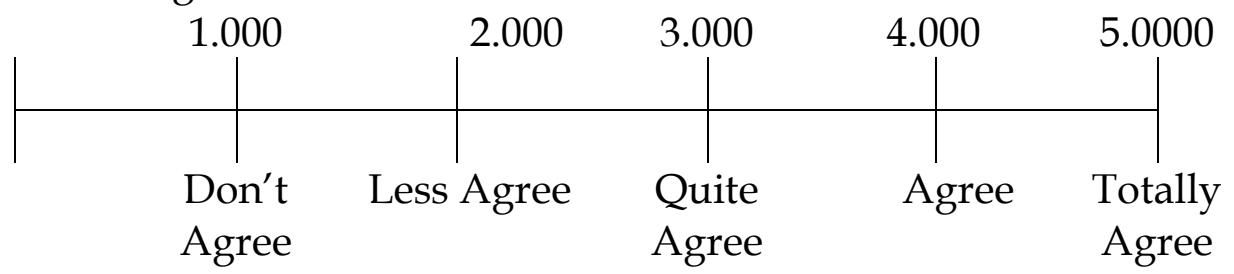

Figure 1.

Likert Scale 
5. Enter the total number of respondents' responses into the Likert scale. The results of this Likert scale calculation infiltration are presented on the following page.

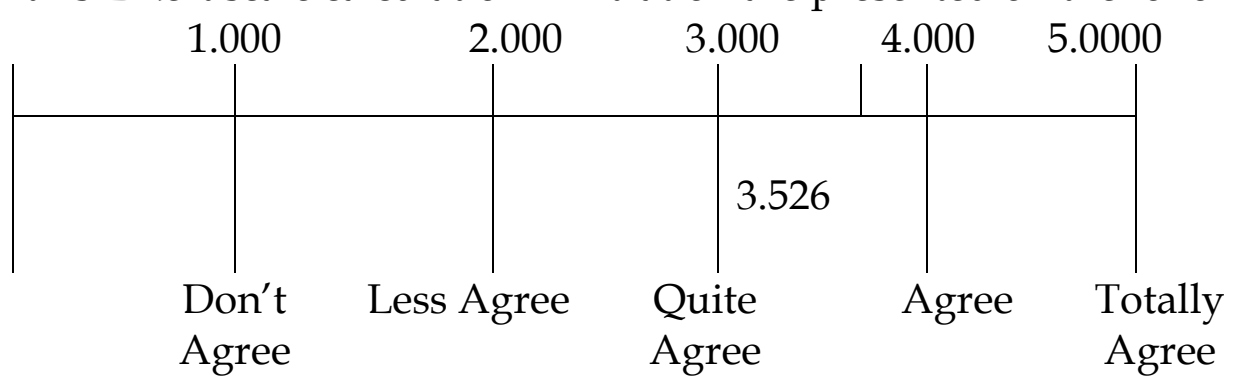

Figure 2.

Illustration of Respondents' Perception Position in Likert Scale

Based on the results of the conversion and calculations above, it can be seen that the number of respondents' responses to the level of customer approval for the implementation of services carried out by the Tangerang City Branch BJB Bank has a value of 3,526. of this value provides a picture above average, based on the Likert scale the value can be categorized into a class between quite agree with agree. Based on the responses from these respondents, it illustrates that the level of customer approval for the implementation of services carried out by the Tangerang City Branch BJB Bank can still be improved so as to provide more satisfaction to customers who receive their services for the future.

The hypothesis design proposed by the researcher is as follows:

$\mathrm{H}_{0}: \beta \leq 0$ : The services provided by the Tangerang City Branch BJB Bank are less able to provide satisfaction to its customers.

$\mathrm{H}_{1}: \beta>0$ : The services provided by the Tangerang City Branch BJB Bank have been able to provide satisfaction to its customers.

With the following test criteria:

$\Rightarrow$ If the Likert Scale calculation value $<60 \%$, then Ho is accepted.

$\Rightarrow$ If the Likert Scale calculation value $\geq 60 \%$, then Ho is rejected.

To get a percentage value regarding customer approval for the implementation of services carried out by the Tangerang City Branch BJB Bank, it can be obtained by comparing the number of respondents' responses with the highest value multiplied by $100 \%$. The result of this calculation is: $\%$ Customer approval for services $=[3,526: 5,000]$ $\mathrm{x} 100 \%=70.52 \%$.

The research result shows that the percentage per disapproval customer service delivery conducted by the Bank BJB Branch Tangerang City is at 70,52\%. This percentage value is greater than the critical value of hypothesis testing, namely $60.00 \%$. With these results it can be concluded that the research hypothesis which states "The services provided by the Tangerang City Branch BJB Bank have been able to provide satisfaction to its customers, because more than $60 \%$ of customers feel dedicated to the services they receive.

For see the Customer Satisfaction Index (IKN) after entered into the formula results are as follows: Based on Table 5. it can be seen that the Customer Satisfaction Index score of 89.53. This value when categorized is included in the service class category A class 
which indicates that the services provided by the Tangerang City Branch BJB Bank are very good. In detail, the results of the calculation of the Customer Satisfaction Index can be seen in table 5 .

Table 5.

Customer Satisfaction Index Value

\begin{tabular}{|c|c|c|c|c|c|c|c|c|c|c|}
\hline No.Soal & 1 & 2 & 3 & 4 & 5 & 6 & 7 & 8 & 9 & 10 \\
\hline TS & 0 & 4 & 0 & 4 & 8 & 0 & 4 & 0 & 0 & 0 \\
\hline KS & 34 & 24 & 12 & 14 & 26 & 0 & 18 & 14 & 10 & 24 \\
\hline CS & 141 & 132 & 126 & 144 & 129 & 138 & 117 & 99 & 123 & 123 \\
\hline S & 60 & 84 & 148 & 92 & 76 & 152 & 140 & 136 & 124 & 116 \\
\hline SS & 105 & 95 & 75 & 90 & 85 & 80 & 65 & 130 & 115 & 90 \\
\hline Total & 341 & 341 & 364 & 348 & 329 & 376 & 351 & 387 & 381 & 363 \\
\hline Weighted & 3,41 & 3,41 & 3,64 & 3,48 & 3,29 & 3,76 & 3,51 & 3,87 & 3,81 & 3,63 \\
\hline $\begin{array}{c}\text { JMLx } \\
\text { Weighted }\end{array}$ & \multicolumn{10}{|c|}{$85,81 \times 0,1=3,581$} \\
\hline IKN & \multicolumn{10}{|c|}{033} \\
\hline
\end{tabular}

Source: Results of Questionnaire Quantitative Data Analysis, 2020 Research

\section{CONCLUSIONS AND RECOMMENDATIONS}

From the results of the calculation of the results of the hypothesis test, the percentage results are $70.52 \%$ This percentage value is greater than the critical value of hypothesis testing, namely $60.00 \%$. Of the five service indicators, namely reliability, responsiveness, assurance, empathy, and tangibility, the analysis results show that empathy has the most dominant influence. The value of the Customer Satisfaction Index (IKN) based on the results of the analysis is 89.53 which is included in the service class category A class which indicates that the services provided by the Tangerang City Branch BJB Bank are very good.

Taking into account the conditions of business competition in banking services, it is recommended that $\mathrm{BJB}$ Bank try to hold promotions, because at present almost companies in similar fields rarely carry out promotions as a marketing strategy, especially to customers from the general public, because so far the intensity of new promotions is in the employee segment. local government. To get feedback positively from the customer, it is recommended that the Bank BJB Branch of Tangerang establish customer forum, so it is possible for the customers who have used other similar banking services, can provide positive input for the Bank BJB Branch of Tangerang City.

\section{REFERENCES}

Amirullah and Haris Budiyono. 2003. Introduction to Management. Second Edition. Graha Ilmu. Yogyakarta.

Arikunto, Suharsimi. 2002. Research Procedure; A Practice Approach. Edition VI. Jakarta: Rineka Cipta.

Balai Pustaka. 2002. Big Indonesian Dictionary. Edition III. Ministry of Education. Jakarta.

Barata, Amsa. 2004. Banking Basics. CV. ARMICO. Bandung. 
Gitosudarmo, 2001. Indriyo and Agus Mulyono. Basic Principles of Management. Sixth Prints. BPFE. Yogyakarta.

Hermawan, Asep. 200 6. Quantitative Pardigm Business Research: Practical Guidelines for Undergraduate, Masters and Doctoral Students Concentration in Marketing, Human Resources, Finance and Operations Management. Grasindo. Jakarta.

Ilyas, Yaslis. 2003 . Service Management Success Tips. Publisher PT. Gramedia Pustaka Utama. Jakarta.

Lupiyoadi, slow. 2002 . Service Marketing Management; Theory and Practice. Four Salemba. Jakarta.

Martoyo, Susilo. 2002 . Human Resource Management. BPFE. Yogyakarta.

Moenir, HAS 2002. Public Service Management in Indonesia. Jakarta: Earth Literacy.

Tangkilisan, Hessel Nogi S. 2005. Public Management. Grasindo. Jakarta. Second printing.

Usmara, A. 200 3. New Marketing Management Strategies. Amara Books. Yogyakarta.

Law Number 14 of 1967 concerning Banking.

Law Number 10 of 1998 concerning Banking Principles. 